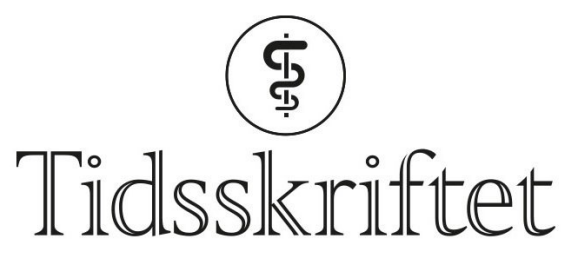

DEN NORSKE LEGEFORENING

\title{
Gastrokirurgi med variasjoner over tema
}

ANMELDELSER

\section{KJETIL SøREIDE}

Overlege, Gastrokirurgisk avdeling Stavanger universitetssjukehus

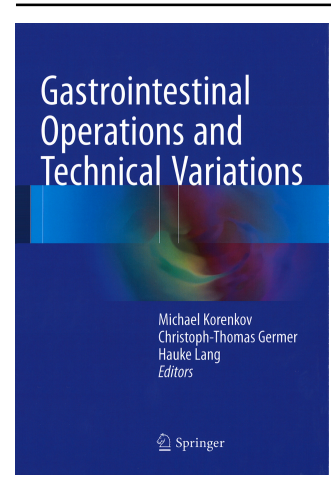

Michael Korenkov

Christoph-Thomas Germer

Hauke Lang, red.

Gastrointestinal operations and technical variations

444 s, tab, ill. Berlin: Springer, 2017. Pris EUR 130

ISBN 978-3-662-49876-7

Dette er en noe annerledes kirurgisk lærebok. Den tar utgangspunkt $i$ at en kirurgisk prosedyre kan utføres under ulike vanskelighetsgrader. En kirurgisk klassifikasjon for vanskelighetsgrader på fire nivåer presenteres i innledningen, hvor nivå I er den vanlige, ukompliserte pasienten, og nivå IV er en pasient hvor de fleste kirurgiske trinn i en prosedyre vil være komplisert som følge av komorbiditet, følgetilstander og tidligere inngrep.

Vanligvis presenteres prosedyrer og inngrep gjennom et standardsett av stegvise tilnærminger mot ett ønskelig endepunkt. Dette får man også presentert i denne boken, men i tillegg har hvert inngrep flere kapitler hvor forfatteren (det vil si kirurgen) forklarer sine variasjoner av inngrepet, gitt vanskelige situasjoner som krever avvik eller modifisering av et standardinngrep. Man skal raskt erkjenne, som redaktørene sier i innledningen, at «the wonderful thing about standards is, that there are so many of them to choose from». 
Temaet er gastrointestinal kirurgi, delt inn i 11 deler som delvis er sykdomsbasert (Individual surgery for upside down stomach and antireflux surgery, Individual surgery for inflammatory bowel disease) eller prosedyrebasert (Individual surgery for right hemicolectomy).

Innbindingen er fast, og papiret er solid og matt. Tabeller i grått er supplert med enkelte fargebilder i kapitlene. Enkelte figurer har tysk bildetekst og figurforklaring, noe som fint kunne vært rettet opp.

Det er ingenting om oesophagus, pancreas eller lever. Gallekirurgi er representert i to kapitler. I totalt 30 kapitler beskriver forfatterne ulike situasjoner og tilstander i kolorektalområdet, og boken har således ikke en bred aktualitet i generell- og gastrokirurgi. Forfatterne kommer fra flere kontinenter, bl.a. USA og Australia, og det er også et flott bidrag fra kolleger i Troms $\emptyset$ om laparoskopisk rektumkirurgi.

Teksten skjemmes dessverre i flere kapitler av dårlig språk, naturlig nok der forfatterne ikke har dette som morsmål. Spesielt oppleves en del av teksten å være nærmest direkte oversatt fra tysk til engelsk, noe som forlaget burde ha språkvasket før utgivelse. En del grammatiske og typografiske feil forekommer også. Boken utgjør imidlertid et interessant konsept. Alle pasienter får jo en ASA-risikoskår ved operasjon, men vi gjør ikke formelt det tilsvarende for selve kirurgien. Kanskje burde vi bevisst gjøre nettopp det.

Boken er et godt supplement til vanlige kirurgiske atlas, hvor man beskriver standardprosedyrer. Nevnte skjønnhetsfeil trekker noe ned, men muligens vil dette kun utbedres og rettes opp i påfølgende utgaver.

Publisert:3. september 2018. Tidsskr Nor Legeforen. DOI: 10.4045/tidsskr.18.0286

(C) Tidsskrift for Den norske legeforening 2020. Lastet ned fra tidsskriftet.no 